e-ISSN: 2776-222X

Vol. 1(2) 2021, pp. 109 - 122

\title{
Development and evaluation of an instructional LiveBinders for learning selected computer studies concept in Ilorin Metropolis
}

\author{
Gboyega Ayodeji Aladesusi*, Fatai Oloruntobi Akindiya \\ University of Ilorin, Nigeria
}

\begin{abstract}
This research was developed and evaluated an instructional LiveBinders for learning selected computer Studies concepts in Ilorin Metropolis, Nigeria. In this research, the design and development model was used. The participants in the study were five computer studies teachers, five computer science experts, and five educational technology experts were chosen at random. The following research instruments were used in this study: a developed computer storage device for computer studies, an expert rating guide of educational technology, and a subject content validation questionnaire. Research questions were answered using percentages and mean. The study concluded that if LiveBinders are properly integrated into learning, computer studies learning can be improved. As a result, it was suggested that students be encouraged to use LiveBinders for learning regardless of a subject area.
\end{abstract}

Keywords: LiveBinders, concretize learning, interest, evaluation

\section{Pengembangan dan evaluasi sebuah pengajaran LiveBinders untuk mempelajari konsep studi komputer di Ilorin Metropolis}

\begin{abstract}
Abstrak: Penelitian telah dikembangkan dan dievaluasi LiveBinders instruksional untuk mempelajari konsep-konsep Studi komputer yang dipilih di Ilorin Metropolis, Nigeria. Dalam penelitian ini digunakan model desain dan pengembangan. Partisipan dalam penelitian ini adalah lima orang guru ilmu komputer, lima orang ahli ilmu komputer, dan lima orang ahli teknologi pendidikan yang dipilih secara acak. Instrumen penelitian berikut digunakan dalam penelitian ini: perangkat penyimpanan komputer yang dikembangkan untuk studi komputer, panduan penilaian pakar teknologi pendidikan, dan kuesioner validasi isi subjek. Untuk menjawab pertanyaan penelitian, persentase dan cara digunakan. Studi tersebut menyimpulkan bahwa jika LiveBinders diintegrasikan dengan benar ke dalam pembelajaran, pembelajaran studi komputer dapat ditingkatkan. Akibatnya, disarankan agar siswa, terlepas dari bidang studinya, didorong untuk menggunakan LiveBinders untuk belajar.
\end{abstract}

Kata Kunci: LiveBinders, pembelajaran konkret, minat, evaluasi

Received: 20-07-2021 Accepted: 05-11-2021
To cite this article: Aladesusi, G. A., and Akindiya, F. 0. (2021). Development and evaluation of an instructional LiveBinders for learning selected computer studies concept in Ilorin Metropolis. Journal of Research in Instructional, 1(2), 109-122. https://doi.org/10.30862/iri.v1i2.13 


\section{INTRODUCTION}

We live in an era where Information and Communication Technology (ICT) is the primary mode of communication (ICT). Through the use of information and communications technology, the world has been reduced to its smallest possible size, making it easier than ever to communicate with anyone in the world at any time. As a result, information and communication technology ensures national development through adequate communication to seek the opinion of anyone in any other country, which brings the deep relationship with other nations to the fore (Oyebola, 2018; Spicher et al., 2021). Technology integration strategies for teaching science are needed because the current teaching methods are ineffective in developing problem-solving skills, curiosity and critical and logical thinking in science students. The most important paradigm shift in the integration of Information and Communication Technology is needed because teaching is based on communication (Shan \& Khan, 2015).

Many people and governments feel that ICT in education makes lifetime learning easier and contributes to the 21st-century skills they may need in the future, hence improving employment and productivity. In addition, despite the lack of data to support these claims, ICT in education is offered as a solution to the teacher shortage. The OECD (Organization for Economic Co-operation and Development) says that ICT would make it more easier for schools and teachers to differentiate their instruction based on students' abilities (OECD, 2017). ICT in education is hindered by a lack of resources and infrastructure in Nigeria, according to research (Ogunode et al., 2021).

As a major tool in education, computers have had a tremendous impact on how we learn and see the world. In today's world, it is impossible to quantify the role of ICTs in education. Smart ICT gadgets on the web enable cutting-edge firms to operate online and in real-time. Modern e-activities like commerce, marketing, healthcare, education, finance, and government have emerged as a result of the technological marvel's impact. Computers and the internet are transforming our lives in profound ways, according to Bamidele (2006), who calls this third wave of ICT development a "global revolution." Teachers' and students' methods of instruction have evolved significantly during the past few years. In addition, it is important to note that the availability of ICTs in schools has a significant impact on the usage of ICTs in teaching and learning activities. It was found that the use of ICT in schools in Sub-Saharan Africa is influenced by a variety of factors. According to Kiptalam and Rodrigues (2012), the integration of technology into education relies heavily on the accessibility and availability of educational resources.

Nigeria, according to this study, would not be an exception..To accommodate this ever-expanding world of information, teachers and students could benefit from an online platform that allows them to collect, share, reflect on, and grow from their learning. The goal is to provide information on how to effectively use an instructional LiveBinders as a family and consumer sciences (FCS) educator. LiveBinders (2015) is defined as a free online bookmarking site that offers a unique method of storing and sharing online resources. LiveBinders allow you to create separate binders for each of your topics, as well as tabs and sub-tabs within each category. This LiveBinder created by David Duff that highlights civil war resources is an excellent example of a LiveBinder (Carver \& Pantoja, 2021).

'Instructional LiveBinders' is a free virtual 3-ring binder that allows you to collect and save various types of media such as documents, links to other websites, PowerPoint 
presentations, photos, videos, and other types of media. In instructive LiveBinders, the ability to view an external link (or another source) within the LiveBinders page is a helpful feature because it avoid reloading the LiveBinders page on a regular basis, which saves time by reducing the need to repeatedly load new windows, media, or pages (unless you want to, and a separate link is provided for that option). A wide range of great instructional LiveBinders are publically available, many of which feature tactics, tools, and other digital material that teachers can use to acquire ideas on a number of topics. Many of these LiveBinders are free to use and can be found on the internet (such as lesson plans for various content areas, school-friendly web tools, Common core, information and resources, and so on). Over 100 LiveBinders have been categorized as relevant to Gifted Education, which will be of particular interest to many of you (Fisher, 2012). For students and teachers alike, LiveBinders is an excellent tool for gathering knowledge and other resources for a number of educational reasons (Tamara, 2012).

ICT has the potential to reduce some of the communication barriers that women face. This includes illiteracy, poverty, time constraints, mobility impediments, and cultural and religious taboos regarding technology. ICT also has the potential to provide tools that can break down barriers to voice, particularly public voice, and social control, such as monitoring women's physical and social mobility (Sidi, 2015). In today's world, computers are being used in almost every facet of human activity. In this continuously expanding and technologically changing world, computer applications have been stressed as a means of increasing efficiency and effectiveness. Because of the rapid expansion of the information age, it is almost guaranteed that computer literacy will have an impact on job chances. Adamu and Bello (2012) argue that computer studies in schools are designed to help students adapt to new technology developments, equip them with the information and skills needed to run a computerized business, and enhance the learning experience. Students are expected to learn more than just what a computer is and what it can accomplish, but rather how to appreciate and use technology. Such teaching methods must ensure that students are able to not only perceive and understand the computer, but also successfully manage their learning and reinforce it, and apply such knowledge or training in a real-world context.

\section{LiveBinders for learning selected computer studies concepts in secondary school}

The noticed that ICT is all about the technology that facilitates the communication process of sending and receiving messages. Technology improvements have led to the creation of communication and multimedia equipment capable of absorbing data, transforming data into information, and storing the information for future reference. Okenwa (2008) agrees with this statement. The use of ICT in education increases educational quantity and quality, resulting in improved innovative, creative, and cognitive thinking, as well as efficiency, increased production, and educational outcomes (Adeosun, 2010). ICT facilitates both the instructional and learning processes and has a significant impact on higher education teaching and learning (Jung, 2005). It enables personalized, flexible, and asynchronous learning, shifts the focus of learning away from the teacher, and thus acts as a catalyst for classroom, community, educational institute, and system reforms. It improves students' learning, assists students in developing new skill sets, fosters social mobility, assists citizens in competing in a global market, and so has a multiplier effect across the educational system (UNESCO, 2014). 
ICT is used for a wide variety of purposes (Ratheeswari, 2018). At the moment, information and communication technology (ICT) pervade every element of human life. They perform critical roles in the business, entertainment industries, education, and workplace. Many people believe that ICT can be catalysts for change in a variety of areas, including working situations, teaching approaches, information management and exchange, scientific research, instructional methods, and access to ICT. In this digital age, the use of information and communication technology (ICT) in the classroom is crucial for providing students with the opportunity to develop and apply necessary 21st-century skills. It is impossible to exaggerate the importance of information and communications technology (ICT) in improving teaching and learning, particularly for teachers in their role as instructional designers. Learning for learners at all levels of educational programs is made possible by ICT, which enables a teacher to communicate his or her instruction in an interesting manner.

\section{Instructional LiveBinders Design Consideration}

Any mix of text, video, audio, still photographs, sound, animation, image, and interactive information that is supplied via computer can be considered an instructional LiveBinder (Sukhendu, 2018). It is generally accepted that LiveBinders is a digital binder that helps instructors organize, bookmark, and share online content as a visual portfolio of their work (collection). The majority of higher education institutions in advanced countries have adopted LiveBinders as a teaching and learning tool. The student engages in three cognitive processes when utilizing LiveBinders for learning. The initial step in cognitive development is the creation of global-rhetorical goals in writing. The principles of coherence, signaling, spatial and temporal contiguity, segmentation, pre-training, modalities, and personalization are all included in this list. In creating educational LiveBinders, these are the guiding principles (Little et al., 2020).

\section{Student Academics Performances on LiveBinders}

Instructional Live Binders act as a conduit between the teacher and the students when it comes to giving instructions to them. They may also serve as a source of inspiration for those involved in the teaching-learning process. Getting students' attention and eliminating boredom (Mason \& Andrews, 2020) are two of the most important goals of this strategy (Raiman et al., 2021). Instructional Live Binders are extremely beneficial for teachers, especially for those who are new to the profession. Instructors rely on instructive Live Binders in every area of their classroom training. There is a requirement for content that provides background knowledge on the topic matter that they are teaching.

According to Crosby and Stelovsky (1995), the impacts of technology-mediated training on learners' academic achievement were measured in comparison to conventional lecture-type instruction. An instructor provided the same lecture to students in both sessions, and students were requested to complete a pretest before beginning the second phase of their study. Afterward, students in one section were exclusively exposed to traditional instruction, whilst students in the other section were exposed to technologymediated learning through the use of online educational resources. Students were invited to complete a posttest after they had finished with the instructions. In their research, the researchers discovered that learners fared better when they were instructed utilizing 
technology, such as courseware, as opposed to traditional methods. In summary, the authors found that courseware improved computer science training and might "make computer science more accessible to a more diversified student population."

\section{Limitation of Integration LiveBinders in Education}

According to Becta (2014), the unavailability of ICT resources is not always due to a lack of software, hardware, or other ICT materials within the school. It could be due to a variety of factors, including low-quality hardware, a lack of personal access for teachers, poor resource organization, or incompatible software. The difficulties associated with teachers' access to new technologies are widespread and vary by country (Empirica, 2016). One of the most major obstacles to implementing ICT in the classroom is a lack of access, and teachers have reported a number of difficulties, including a shortage of computers and adequate materials.

According to Oshinaike and Adekunmisi (2017), in their study on the use of instructional tools for teaching in the Nigerian University System, using the University of Ibadan as a case study, the limitations associated with effective use of instructional tools in teaching include lecturers' use of instructional material resources in forming lecture notes for teaching students, research, paper presentations, and publication activities. A lack of support infrastructures, a lack of time to devote to technology, insufficient or no training, insufficient funding for individual lecturers, and the expensive cost of technology were some of the main challenges restricting the use of instructional technologies in education. After that, he argued that the school should recommend that university lecturers be given training and development skills in the use of these high-tech facilities; ICT training should be provided to instructors and other members of university employees on the integration of technology in instruction; and finally, if a problem arises as a result of the resources being used, adequate, competent, and knowledgeable staff should be available to assist students in resolving the issue.

Some researchers, such as Aminu et al. (2021), believe that the high development cost of instructional tools, the time required in the process of developing effective instructional tools, and the difficulty of training educators who are unfamiliar with the production and design of instructional tools courseware or packages are some of the limitations of integrating educational technology as a tool in education. Tan (2000), as cited in Mpungose (2020), also stated that some of the problems with instructional tools for teaching are: first, some teachers failed to recognize the relevance of classroom instruction during the courseware design process, resulting in an abundance of knowledge but an inability to emphasize the significance of classroom instruction; and second, in the practical teaching process, students' questions frequently rely on teachers' answers, particularly in explaining definition and practice. Teachers' negative attitudes toward teachers and their lack of knowledge about technology integration have been identified as the primary barriers to technology integration in education (Uslu \& Bumen, 2012).

According to studies, teachers' attitudes, ICT competence, knowledge, computer selfefficacy, teaching experience, gender, and teacher workload, as well as institutional characteristics such as accessibility, technical support, leadership support, and training, as well as technological characteristics such as consistent performance with teachers' existing 
values, previous experiences and needs, and ease of use, are some of the factors that influence teachers' use of ICT and e-Learning systems, among other things.

\section{Purpose of the study}

The main purpose of this study was to develop and evaluate instructional LiveBinders for learning selected computer studies concepts in the Ilorin metropolis. Specifically, the study;

1. Developed instructional LiveBinders for learning selected computer studies concepts in Ilorin metropolis.

2. Examined Educational technology expert rating of the developed LiveBinders for learning selected computer studies concepts in Ilorin metropolis.

3. Determined computer science expert rating of the developed LiveBinders for learning selected computer studies concepts in the Ilorin metropolis.

4. Examined computer studies teachers rating of the developed LiveBinders for learning selected computer studies concepts in Ilorin metropolis.

\section{METHOD}

This research would use design and development. The systematic study of design, development, and evaluation processes with the goal of establishing an empirical basis for the creation of instructional and non-instructional products and tools, as well as new or improved models that govern their development, is known as model type research (Richey \& Klein, 2007). This study used a single pre-experimental sample and expert validation.

The study used a significant learning-integrated course. (Fink, 2003) developed a comprehensive description of an integrated approach to designing college courses. Identifies the components of the model. It implies that, in order to design any type of instruction, the teacher must:

1. Identify critical Situational Factors

2. This data should be used to make three major decisions:

a. What do I want students to understand? (Learning Objectives).

b. How will students (and the teacher) know if these objectives have been met? (Feedback and Evaluation)

c. What would the teacher and students need to do for students to meet the learning objectives? (Activities for Teaching/Learning)

3. Ensure that these critical components are included (that is, that they support and reinforce each other).

The principles of online design were also used to guide the creation and development of an instructional video. Similar to LiveBinders, the study would use a pre-experimental design. The most basic type of research design is pre-experimental. In a pre-experiment, either a single group or multiple groups are observed following the application of some agent or treatment that is thought to cause change.

This study's population included all computer science experts, educational technology experts, and teachers of computer studies in Nigeria. The target population would be computer science experts, educational technology experts, and computer studies teachers in the Ilorin metropolis. Purposive sampling techniques were used to select five (5) Educational Technology experts, five (5) Computer Science experts, five (5) Computer 
teachers. The experts were selected on the basis of their accessibility to internet, experiences as teachers of the subject area and availability of tools to access the internet.

Four research questions were used for data collection in this study the instruments were; Developed instructional LiveBinders, Educational Technology expert's questionnaire (ETEQ), Computer science expert's questionnaire (ESEQ) and computer studies teacher questionnaire (CSTQ). The expert rating questionnaire were given to experts for experts' validation of the live binder. The expert writes down professional comment, observation, and suggestions to improve the quality of the LiveBinders. The expert rating questionnaire were rated on a 4-point Likert scale mode: Excellent (5); Very good (4); Good (3); Fair (2); Poor (1).

Validation of the live binder was carried out through expert's validation. In order to ensure content and construct validation, the instructional live binder was validated by 10 experts from 2 department from University of Ilorin and 5 computer studies teachers from Ilorin metropolis, for scrutiny and expertise assessment. However, with the Rectification and statement given by the experts, the questionnaire would authenticate and found to be relevant for the purpose for which it was designed for. Lecturers from the department of Educational Technology affirmed that the content of the instructional package was adequate and relevant to instructional purposes. The educational technology experts responded to the instrument by rating the package using the expert validation instrument based on the structure, design factor, effectiveness.

However, the computer science experts checked the functionality of the package, the programming language used as well as the database created. Generally, the experts adjudged the instructional package to be functionally good; easy to use; and user friendly. The experts' view about the package was analyzed.

Also, computer studies teacher checked if it meets the requirement it was specifically set for in this study and can be used as a means of student-centered learning activity. The package was reviewed and analyzed. The figures below shows the screen shot of the LiveBinders environment.

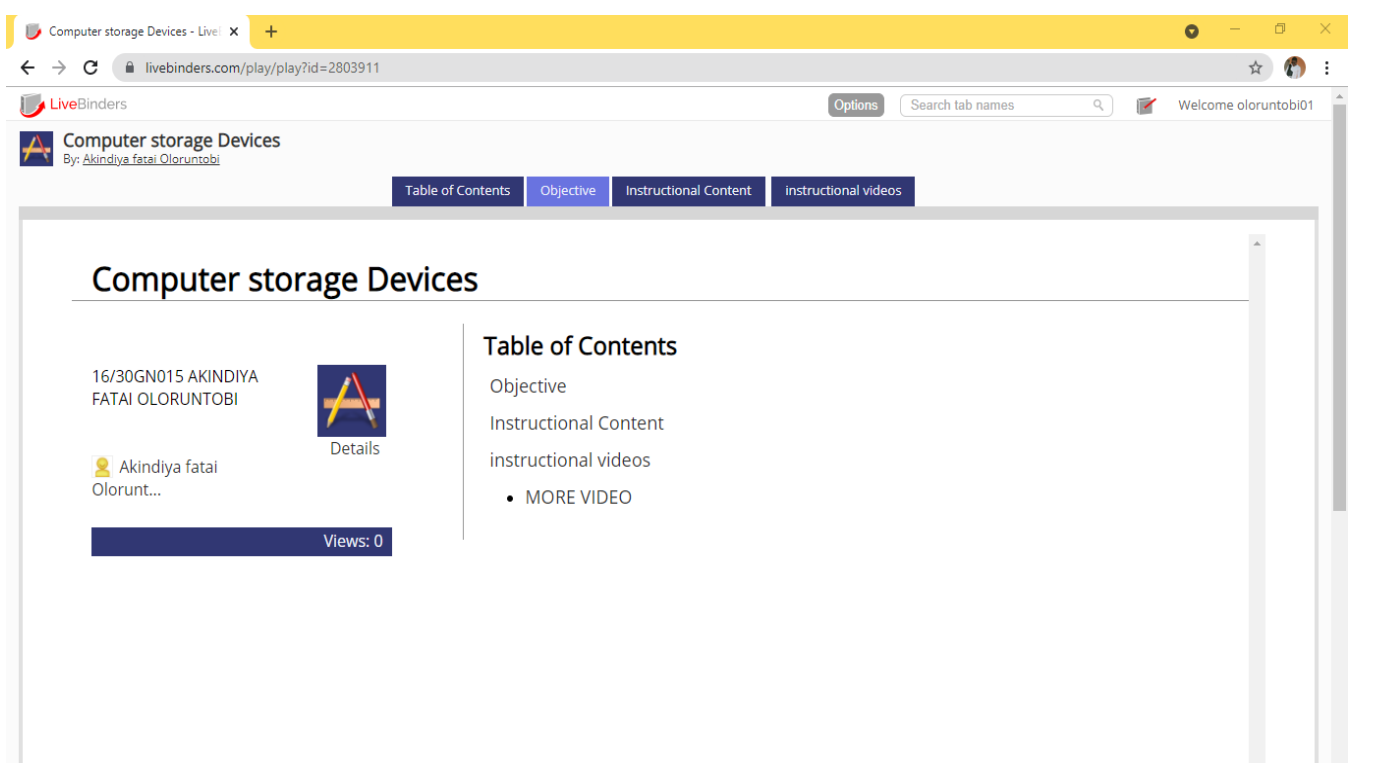

Fig. 1. Frist screenshot of the LiveBinders environment 


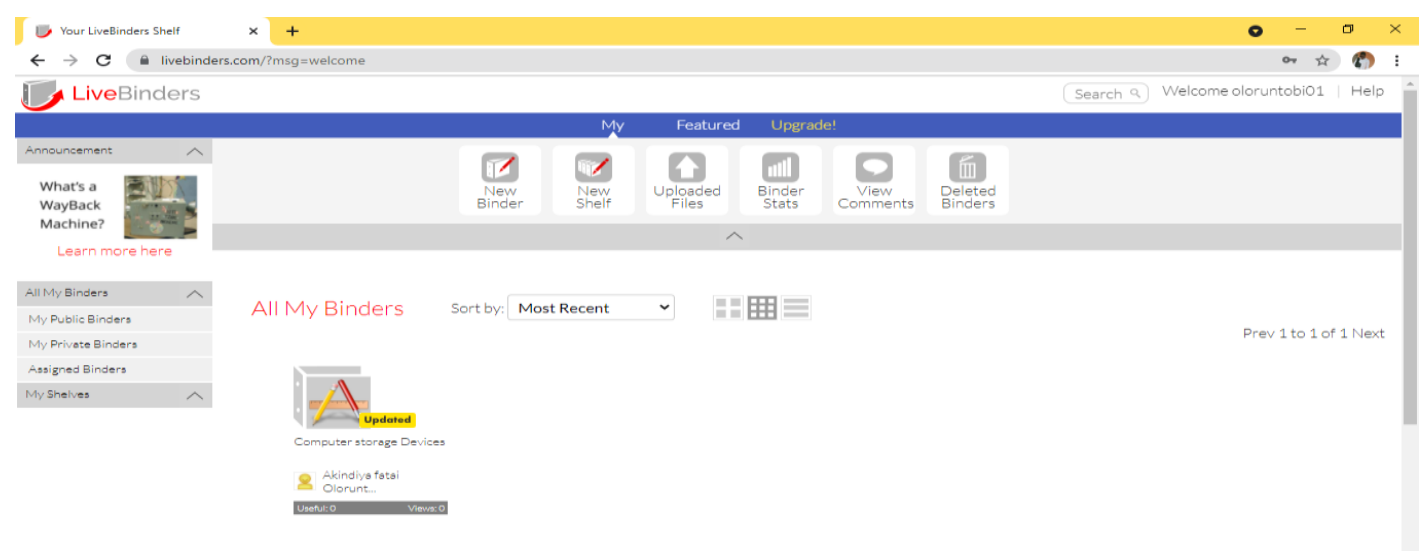

Fig. 2. Second screenshot of the LiveBinders environment

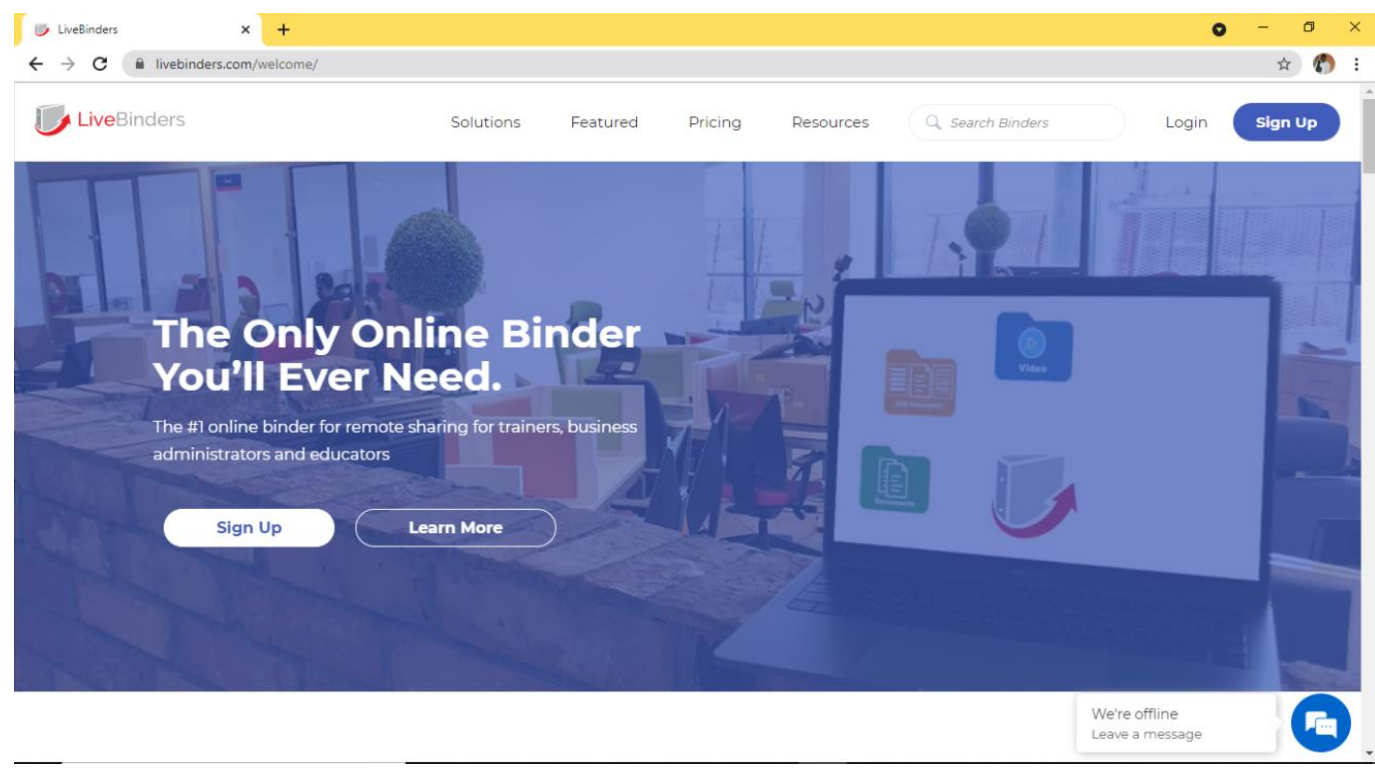

Fig. 3. Third screenshot of the LiveBinders environment

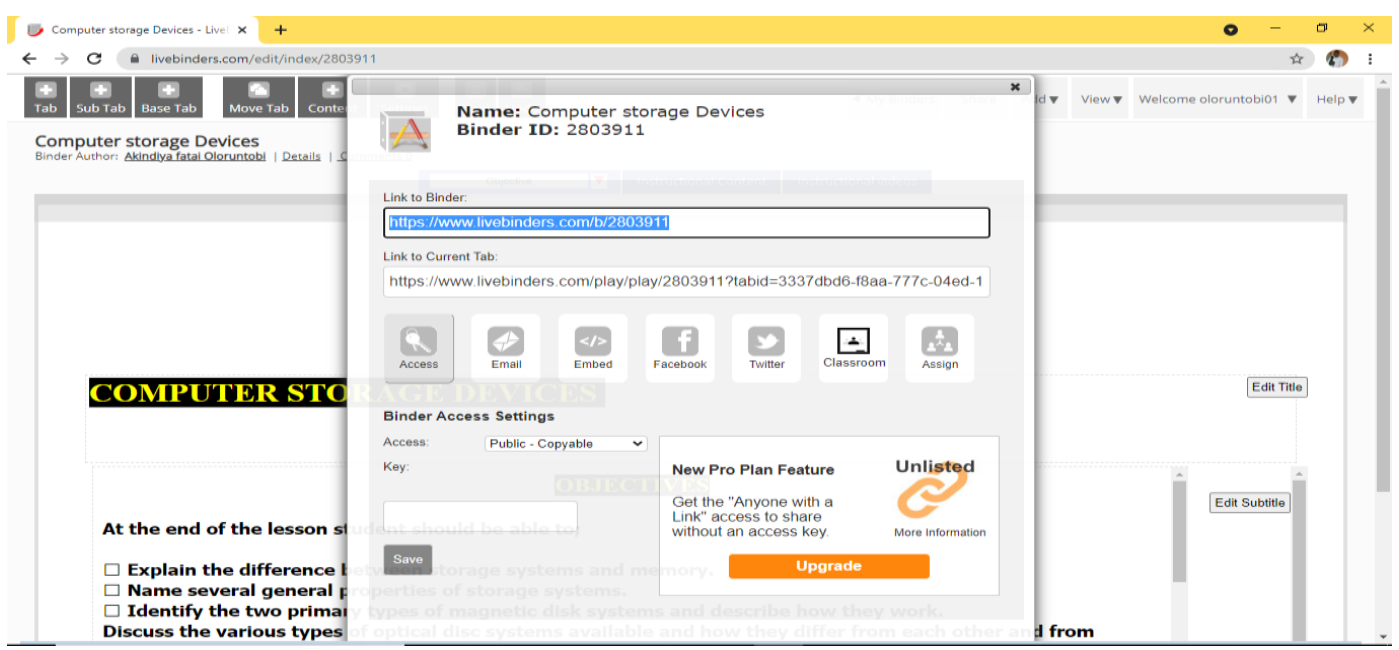

Fig. 4. Fourth screenshot of the LiveBinders environment 
The researcher administered the questionnaire directly on the selected experts' respondent in Ilorin, Kwara state, the researcher obtained permission to carry out the administration of the questionnaire from the Head of the department of Educational Technology; faculty of Education University of Ilorin, to the selected individual expert was used for this study. After the respondent willingness and readiness, the questionnaire was administered to 5 Educational Technology experts, Computer science expert and computer studies experts. Thereafter, the researcher allowed the experts to go through the instructional package for few minutes, deliver the questionnaire and after the completion it was collected back from the respondent immediately. Few questionnaires will be distributed and retrieved immediately after filled for accurate retrieval. The experts' rating of the LiveBinders were analyzed using descriptive statistics. Research questions were answered using mean, percentages and weighted mean score with the aid of Product service solution (SPSS).

\section{RESULTS}

Table 1 reveals the distribution of the expert who rated the LiveBinders for instructional delivery. The table indicated that 5(33.3\%) Educational Technology Experts, Computer science expert and computer studies experts were participant in the study. In all $15(100 \%)$ were participant in the study.

Table 1: Distribution of expert for the study

\begin{tabular}{lll}
\hline Experts & Frequency & Percentage (\%) \\
\hline Educational Technology Experts & 5 & 33.33 \\
\hline Computer Science Experts & 5 & 33.33 \\
\hline Computer studies Expert & 5 & 33.33 \\
\hline Total & 15 & 100 \\
\hline
\end{tabular}

Research Question One: What are the processes involved in developing LiveBinders in computer studies for secondary schools in the Ilorin metropolis?

The development of LiveBinders in computer studies for secondary schools in the Ilorin metropolis was carried out using Product Oriented Model, a front-end system design with four stages (development / production of material, selection of media, course outline, and course delivery). The course outline was selected from the computer studies syllabus. The images and audio file were downloaded from open-sourced websites, most especially Google. The downloaded images and audio were further arranged and developed using Microsoft Office 2016 PowerPoint in a logical and sequential manner to create a series of images with captions explaining each Storage device and its function.

\section{Research Question Two: How do educational technology experts rate the developed LiveBinders on computer studies for secondary schools in Ilorin metropolis?}

To answer research question two, a computer science expert rating guide was used in the validation of the developed LiveBinders for secondary schools in Ilorin metropolis. The data were analyzed using mean, while mean was used to determine the validation rate developed LiveBinders on secondary schools in the Ilorin metropolis. The bench mark of 3.0 of a 5-point Likert scale was adopted. Results of the analysis are shown on Table 2. 
Table 2. Mean of educational technology experts on a developed LiveBinders

\begin{tabular}{|c|c|c|}
\hline No & Statement & Mean \\
\hline 1. & $\begin{array}{l}\text { The structure of the package allows learners to explore, learn, understand } \\
\text { educational concept. }\end{array}$ & 5.00 \\
\hline 2. & The user experience is friendly. & 4.00 \\
\hline 3. & The presentation of information can captivate student's attention. & 4.67 \\
\hline 4. & The LiveBinders is developed and presented in a clear and understandable & 4.00 \\
\hline 5. & The package can be used in different platforms. & 4.67 \\
\hline 6. & Package allows learner to learn at their own pace. & 4.67 \\
\hline 7. & The package can be modified or updated. & 4.00 \\
\hline 8. & Package was developed using the instructional system design (ISD) & 5.00 \\
\hline 9. & The package is designed in a clear and understanding manner. & 4.33 \\
\hline \multirow[t]{2}{*}{10.} & The LiveBinders is clear, precise and appealing. & 4.33 \\
\hline & Mean & 4.47 \\
\hline
\end{tabular}

Table 2 indicates the mean of educational technology experts on a developed LiveBinders on computer studies for secondary schools in Ilorin metropolis. The table revealed that the mean score of educational technology experts' rating of a developed LiveBinders on computer studies for secondary schools in Ilorin metropolis is 4.47 which is higher than the benchmark of 3.00. This implies that the developed LiveBinders was well structured and every expectation in the developed live binders was achieved.

\section{Research Question Three: How do computer science expert rate the developed instructional LiveBinders for learning selected computer studies concept in Ilorin metropolis?}

In order to determine validation of computer science expert rating of the developed LiveBinders in secondary schools. A subject content validation questionnaire was used. The data collected were analysed while mean was used to determine the overall computer science expert rating of the developed instructional LiveBinders for learning selected computer studies concept in Ilorin metropolis. The bench mark of 3.0 of a 5 point Likert scale was adopted. Results of the analysis are shown on Table 3.

Table 3. Mean of computer science expert

\begin{tabular}{clc}
\hline S/N & \multicolumn{1}{c}{ Items } & Mean \\
\hline 1. & The package is easy to operate for both learners and teachers. & 3.40 \\
\hline 2. & The LiveBinders is user-friendly. & 3.61 \\
\hline 3. & The content can be updated and modified with new knowledge. & 3.62 \\
\hline 4. & Video quality in the LiveBinders is of good quality. & 3.20 \\
\hline 5. & Screens are designed in a clear and understanding manner & 3.60 \\
\hline 6. & LiveBinders allows learners to learn, understand computer studies & 3.63 \\
& concept. & \\
\hline 7. & The update and procedures are relatively easy for the average user. & 3.62 \\
\hline 8. & LiveBinders allows learner to learn at their own pace. & 3.81 \\
\hline 9. & Technical Support needed for package use in the classroom. & 4.00 \\
\hline 10. & A high contrast between graphics and background is retained. & 3.81 \\
\hline & & Mean \\
\hline
\end{tabular}


Table 3 indicates the mean responses of the computer science experts in secondary schools to the developed Livbinders. Using a bench mark of 3.0, the mean result revealed that the mean score for each of the ten (10) items on the questionnaire is above 2.5 , while, the mean score of the ten (10) items is 3.64. This indicates that computer science expertsrated the developed live binders high for learning.

\section{Research Question Four: What is the computer studies teacher's rating of the developed instructional LiveBinders for learning selected computer studies concept in Ilorin metropolis?}

In order to determine validation of computer studies teachers rating of the developed LiveBinders in secondary schools. A subject content validation questionnaire was used. The data collected were analysed while mean was used to determine the overall computer studies teachers of the developed instructional LiveBinders for learning selected computer studies in Ilorin metropolis. The bench mark of 3.0 of a 5-point Likert scale was adopted. Results of the analysis are shown on Table 4 and interpreted as thus.

Table 4. Mean of computer Studies Teachers Rating of the Developed LiveBinders

\begin{tabular}{clc}
\hline S/N & \multicolumn{1}{c}{ Items } & Mean \\
\hline 1. & The instructional objective is carefully stated and analyzed. & 3.20 \\
\hline 2. & Content is rich enough to enhance learning. & 3.31 \\
\hline 3. & The LiveBinders is clear, precise, and appealing & 3.32 \\
\hline 4. & The LiveBinders content contains learned-centered instructions. & 3.10 \\
\hline 5. & The package will enable the students to achieve the main objectives. & 3.40 \\
\hline 6. & The package gives room for feedback. & 3.13 \\
\hline 7. & The developed LiveBinders does not overload students' memory. & 3.12 \\
\hline 8. & The package can be used beyond the classroom for students' personal & 3.81 \\
& use. & \\
\hline 9. & Teachers can use LiveBinders effectively for the students & 4.00 \\
\hline 10. & The level of content and vocabulary are appropriate for the intended & 3.81 \\
& audience & Mean \\
\hline
\end{tabular}

Table 4 indicates the mean responses of the computer studies teachers in secondary schools to the developed Livbinders. Using a benchmark of 3.0, the mean result revealed that the mean score for each of the ten (10) items on the questionnaire is above 2.5; while, the mean score of the ten (10) items is 3.54. This indicates that computer studies teachers rated the developed Live binders high for learning.

\section{DISCUSSION}

Findings revealed that the development of a LiveBinders in computer studies for secondary schools in the Ilorin metropolis can be done using product-oriented model which is a front-end system design with four stages (Development/ Production of material, Selection of Media, Course Outline, and Course Delivery). These findings complement the assertion of (Dick, Carey \& Carey, 2005) who made a significant effort to build on the ADDIE model and postulated that the design of instruction and classroom instructional materials 
should be based on a whole system that focuses on the interrelationship between contexts, content, learning and instructional technique.

Findings also revealed that the developed live binder for computer studies was well structured and every expectation in the developed live binders was achieved. This finding is consistent with the findings of Marie-Perry (2013), and Eick and King (2012), who revealed that a photo and video series resulted in higher scores on standardized measures of achievement and was also rated higher as an attitude instrument. There is evidence not only of achievement but also of attitude improvement. Findings revealed that computer studies have a positive reaction to the developed LiveBinders. This is in line with the assertion of Aladesusi (2022), the researcher opined that visual materials had been an important component of the classroom over the years, and teachers have a positive reaction to the use of visual materials in the classroom. The researcher claimed that visual materials such as film strips, pictures, slides, and pass-around objects are mostly liked and utilized by teachers in the classroom compared to other instructional materials. Thus, visual materials such as LiveBinders are considered a useful tool for teachers in almost every trend of classroom instruction.

The study was limited to visual elements without explanatory audio to support the LiveBinders. The study was limited to 5 computer science teachers and five computer teacher experts for validation purposes, so it might be difficult to generalize the findings of this study. The positive result gained from this study might be due to the location where this study was conducted, due to the fact that Ilorin metropolis is the business hub and elite filled environment.

\section{CONCLUSION}

The research paper concluded that visual aids such as LiveBinders are an influential tool in the classroom and can improve computer science teaching in Nigeria, particularly in the Ilorin metropolis. The teachers appreciate LiveBinders, and they are ready to use it in the classroom to allow learners to visualize materials that are not readily available in the school and show the actual meaning of the lesson content. This conclusion is based on the mean rating revelation that shows positive. The study, therefore, recommended that LiveBinders should be adopted for the teaching of computer studies in secondary schools in order to concretize lesson content and abstract content that are inherent in computer studies, and teachers of computer studies should be adequately and properly trained to utilize emerging technologies that are useful for the teaching of computer studies.

\section{REFERENCES}

Adamu, S .H \& Bello, A. (2012). Computer education in Nigeria school. Nigeria journal of computer literarcy, 2(4), 96-102.

Adeosun, O. (2010). Quality basic education development in Nigeria. Journal of International Cooperation in Education, 2(2), 193-211.

Aladesusi G. A., Nifemi, A. O., \& Omolara, O. T. (2022). Development and evaluation of lessoncast in learning selected basic technology concept in Ilorin Metropolis. Indonesian Journal of Educational Research and Technology, 2(1), 21-36.

Aminu, N., Hamdan, M., \& Russell, C. (2021). Accuracy of self-evaluation in a peer-learning environment: An analysis of a group learning model. SN Social Sciences, 1(7), 1-17. 
Bamidele, S. O. (2006). Development of modern ICT and internet system. Information and comunication technology and computer applications, 2(1). 1-3.

Becta. (2014). What the research says about using ICT. Journal of technology Education $3(2), 1-9$.

Carver, L., \& Pantoja, L. (2021). Visual and Auditory Production. In L. Carver \& H. S. Atkins (eds.), Leading in the Digital Environment: Being a Change Agent. Rowman \& Littlefield.

Crosby, M. E., \& Stelovsky, J. (1995). From multimedia instruction to multimedia evaluation. Journal of Educational Multimedia and Hypermedia, 4, 147-162.

Dick, Carey \& Carey. (2005). The Systematic Design of Instruction. Pearson/Allyn and Bacon

Eick, C. J., \& King Jr, D. T. (2012). Nonscience Majors' Perceptions on the Use of YouTube Video to Support Learning in an Integrated Science Lecture. Journal of College Science Teaching, 42(1).

Empirica. (2016). Benchmarking access and use of ICT in school. Report from head Teacher and Classroom 7(2),11-21.

Fink, L. D. (2013). Creating significant learning experiences: An integrated approach to designing college courses. John Wiley \& Sons.

Fisher. (2012). Information resourse. Journal on livebinder, 2(1),1-3.

Jung, I. (2005). ICT-pedagogy integration in teacher training: Application cases worldwide. Journal of Educational Technology \& Society, 8(2), 94-101.

Kiptalam, G. K., \& Rodrigues, A. J. (2010). Accessibility and utilization of ICTs among secondary school teachers in Kenya. The International Conference on Computing and ICT Research, 246-263.

Little, M., Cohen-Vogel, L., Sadler, J., \& Merrill, B. (2020). Moving kindergarten entry assessments from policy to practice evidence from North Carolina. Early Education and Development, 31(5), 796-815. https://doi.org/10.1080/10409289.2020.1724600

Mason, L. L, \& Andrews, A. (2014). Referent-Based Verbal Behavior Instruction for Children with Autism. Behavior Analysis in Practice, 7(2), 107-111. https://doi.org/10.1007/s40617-014-0018-z

Merry-Perry, M. J. M. (2013). Effects of visual media on achievement and attitude in a secondary biology classroom. A Master's Research Project Presented to The Faculty of the Patton College of Education and Human Services Ohio University.

Mpungose, C. B. (2020). Are Social Media Sites a Platform for Formal or Informal learning? Students' Experiences in Institutions of Higher Education. International Journal of Higher Education, 9(5), 300. https://doi.org/10.5430/ijhe.v9n5p300

OECD. (2017). Panorama da la education. information commucation and technology in education , 4(1),13-22.

Ogunode, N. J., Hammadu, M., Ahmed, I., \& Ojo, I. C. (2021). Challenges Preventing Students in Public Tertiary Institutions from Using Information Communication Technology for Learning in Nigeria and the Way Forward. Pindus Journal of Culture, Literature, and ELT, 9, 9-17.

Okenwa. (2008). Meetting the challenges of information technology. case for reform in distance education programme, (pp. 197-202). Nsukka. 
Oshinaike \& Adekunmisi. (2017). Use of multimedia for teaching in Nigerian. a case study of University of Ibadan. Library Philosophy and Practice, 9(2), 13-15.

Oyebola. (2018). National development on ict. ICT , 2(1), 1-3.

Raiman, M., Liu, A. N. A. M., \& Wolo, D. (2021). Investigation of students' motivation to learn science while studying from home during a pandemic. Journal of Research in Instructional, 1(1), 33-42. https://doi.org/10.30862/jri.v1i1.10

Ratheeswari, K. (2018). Information communication Technology. Journal of Applied and Advance Research 2(6), 9-12 .

Richey \& Klein. (2007). Developmental research: Studies of instructional design and development. Handbook of research for educational communication and technology, 6(1), 1099-1130.

Shan \& Khan . (2015). strategies on teaching. integration Of Information And Communication Technology, 5(1), 2-4.

Sidi. (2015). Human right in general and womens right. Gender Access to ICT, 2(4), 1-4.

Spicher, N., Barakat, R., Wang, J., Haghi, M., Jagieniak, J., Öktem, G. S., Hackel, S., \& Deserno, T. M. (2021). Proposing an international standard accident number for interconnecting information and communication technology systems of the rescue chain. Methods of Information in Medicine, 60(S-01), 20-e1. https://doi.org/10.1055/s-0041-1728676

Sukhendu. (2018). Principle of learning. LiveBinder, 5(2),1-3.

Tamara. (2012). Resourses for various educational purposes. journal on livebinder , 1-3.

UNESCO. (2014). Information and communication technology in education. A comprarative analysis of ICT integration in school, 4(3), 11-22.

Uslu, O., \& Bumen, N. T. (2012). Effects of the professional development program on Turkish teachers: Technology integration along with attitude towards ICT in education. Turkish Online Journal of Educational Technology-TOJET, 11(3), 115-127. 